9. Schmidt, J.O., Thoenes, S.C., Hurley, R.: ibid. 129, 468 (1989)

10. Schmidt, J.O., Thoenes, S.C.: Bull. Ent. Soc. Am. 33, 155 (1987)
11. Lindauer, M.: Naturwissenschaften 38 , $509(1951)$

12. Mautz, D., Boch, R., Morse, R.A.: Ann. Ent. Soc. Am. 65, 440 (1972)
Avitabile, A., Morse, R.A., Boch, R.: ibid. 68, 1079 (1975)

13. Seeley, T.D., Morse, R.A., Visscher, P.K.: Psyche 86, 103 (1979); unpublished observations
Naturwissenschaften 80, 575-578 (1993) C Springer-Verlag 1993

\section{Spectral Phase Sensitivity in the Communication of a Wave-Type Electric Fish}

\author{
B. Kramer and H. TeubI \\ Zoologisches Institut der Universität, D-93040 Regensburg
}

The knifefish Eigenmannia discharges its electric organ in a species-characteristic, quasi-sinusoidal waveform of constant frequency for communication and electrolocation. In contrast to the human who relies on spectral amplitude cues (in the frequency domain) for discriminating between sounds (for example, voices) by their differences in timbre, Eigenmannia is also sensitive to "pure" waveform differences of an electrical signal (due to differences in phase spectra, in the time domain; [1]). Here, we report that the threshold phase shift of an artificial Eigenmannia-like signal's second harmonic relative to the first is less than $22^{\circ}$, as shown by conditioned discrimination. Naïve Eigenmannia show a spontaneous preference for the artificial waveform with a phase spectrum similar to their species' discharge rather than an alternative waveform having an identical amplitude spectrum (indistinguishable for the human ear when made audible).

In its natural Amazonian habitat Eigenmannia coexists with many other gymnotiform electric fishes displaying species-characteristic discharge waveforms [2-5]. Eigenmannia discriminates $[6,7]$ the individually variable and sexually dimorphic [8] discharge waveforms of conspecifics; however, the sensory mechanism had not been studied until recently [1].

In gymnotiforms with a pulse discharge, sensitivity to a polarity reversal of discharge-like stimulus pulses of natural [9] or unnatural [10] waveforms has been demonstrated (that is, a $180^{\circ}$ phase shift). Also, in the unrelated, weakly electric Mormyridae (elephantfishes) evidence for a sensitivity to differences or changes in their pulse discharge waveform has been reported, in both a communication [11-13] and an electrolocation or object detection context $[14,15]$. In order to test Eigenmannia's sensitivity
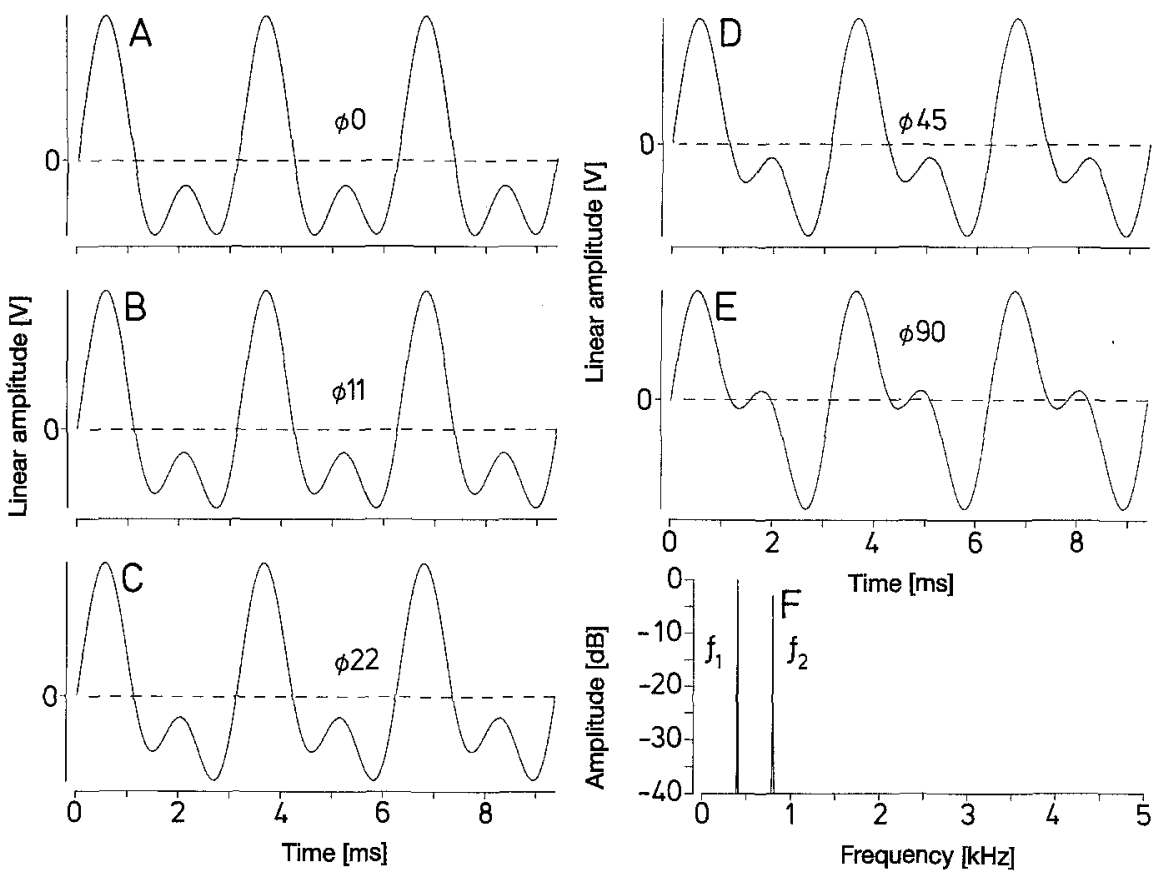

for pure waveform differences, entirely artificial signals of identical amplitude spectra were used (Fig. $1 \mathrm{~A}-\mathrm{E}$ ). These consisted of only two harmonically related sine waves which were numerically superimposed, a fundamental frequency or first harmonic, $f_{1}$, and its second harmonic, $f_{2}$, of twice that frequency and variable phase delay, $\varnothing$, between $11^{\circ}$ and $90^{\circ}$. The $f_{2}$ harmonic was exactly $3 \mathrm{~dB}$ weaker than the fundamental in all signals (Fig. $1 \mathrm{~F}$, Table 1 ), as may also be observed in an Eigenmannia male discharge [8]. (The electric organ discharge of an Eigenmannia also contains a few still higher harmonics of rap-
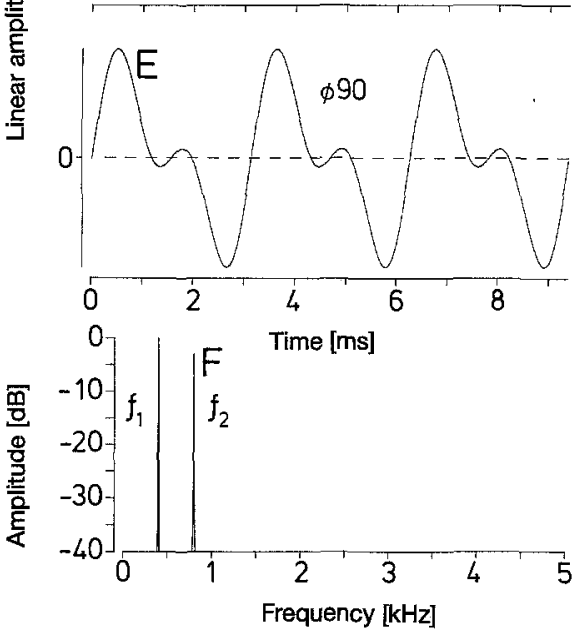

Fig. 1. Stimulus waveforms (A-E) as used in training experiments and for investigating a spontaneous preference $(\mathrm{A}, \mathrm{E})$. All signals have an identical amplitude spectrum $(\mathrm{F})$, showing a fundamental frequency, $f_{1}$, and the second harmonic, $f_{2}$, which is $3 \mathrm{~dB}$ weaker (further harmonics were less than $-50 \mathrm{~dB}$ ). The only difference between the signals is the variable phase delay, $\emptyset$, of $f_{2}$ relative to $f_{1}$, from $0^{\circ}$ (A) to $90^{\circ}$ (E). The signals were computed as $y=\sin \omega t+a \sin (2 \omega t+\emptyset)$ (where $\omega=2 \pi f, f$ frequency, $t$ time, $a$ amplitude, and $\emptyset$ phase difference relative to the amplitude peaks of the sine waves). The signals were played back through a dipole model of an electric fish which exactly imitated the electric field of a conspecific, except for the artificial waveform. The amplitude spectrum in (F) is a fast-Fourier transform of a 1024-point digital representation of each waveform, sampled at $12 \mathrm{bit} / 10 \mathrm{kHz}$. Stimulus frequencies were adjusted to $30 \mathrm{~Hz}$ above the discharge frequency of a fish for conditioning experiments. Stimulus rise and fall times were $400 \mathrm{~ms}$. For a full account of methods, see [1] 
Table 1. Relative intensity relationships of the $\mathbf{S}+$ and $\mathbf{S}$ - signals, of identical amplitude spectra but different waveforms because of a variable phase delay, $\emptyset$, of the $f_{2}$ harmonic between $0^{\circ}$ to $45^{\circ}$ (see Fig. 1). The letters H (high) or L (low) designate S- signals of either identical energy contents $(H)$ as compared to the $S+$, or identical peak-to-peak amplitude (L). Also given is the sine wave reference signal used for calibration, the intensity of which was $270 \mu \mathrm{V}_{\mathrm{p}-\mathrm{p}} \cdot \mathrm{cm}^{-1}$ at the resting position of the fish at $30 \mathrm{~cm}$ distance from the dipole, that is, $43 \mathrm{~dB}$ above threshold of the unconditioned response. Water conductivity was $100 \pm 1 \mu \mathrm{S} \cdot \mathrm{cm}^{-1}$, or a resistivity of $10 \mathrm{k} \Omega \cdot \mathrm{cm}$. Amplitude r.m.s. root mean square amplitude. For methods, see $[1,20]$

\begin{tabular}{|c|c|c|c|c|}
\hline Stimulus & $\begin{array}{l}f_{1} \text { Inten- } \\
\text { sity }\end{array}$ & $\begin{array}{l}f_{2} \text { Phase } \\
\text { re } f_{1}\left(^{\circ}\right)\end{array}$ & $\begin{array}{l}\text { Amplitude } \\
\text { peak-to-peak }\end{array}$ & $\begin{array}{l}\text { Amplitude } \\
\text { r.m.s. }\end{array}$ \\
\hline$S+(\omega 0)$ & 1.00 & 0 & 1.31 & 1.21 \\
\hline $\begin{array}{l}\text { Sine wave } \\
\text { (reference) }\end{array}$ & 1.00 & $\begin{array}{l}\left(f_{2} \text { below }\right. \\
\text { detection })\end{array}$ & 1.00 & 1.00 \\
\hline$S-(\varnothing 45 \mathrm{H})$ & 1.00 & 45 & 1.45 & 1.21 \\
\hline $\mathrm{S}-(\phi 45 \mathrm{~L})$ & 0.88 & 45 & 1.31 & 1.07 \\
\hline $\mathrm{S}-(\emptyset 22 \mathrm{H})$ & 1.00 & 22 & 1.41 & 1.21 \\
\hline$S-(\varnothing 22 \mathrm{~L})$ & 0.93 & 22 & 1.31 & 1.12 \\
\hline $\mathrm{S}-(\emptyset 11 \mathrm{H})$ & 1.00 & 11 & 1.36 & 1.21 \\
\hline $\mathrm{S}-(\varnothing 11 \mathrm{~L})$ & 0.96 & 11 & 1.31 & 1.17 \\
\hline
\end{tabular}
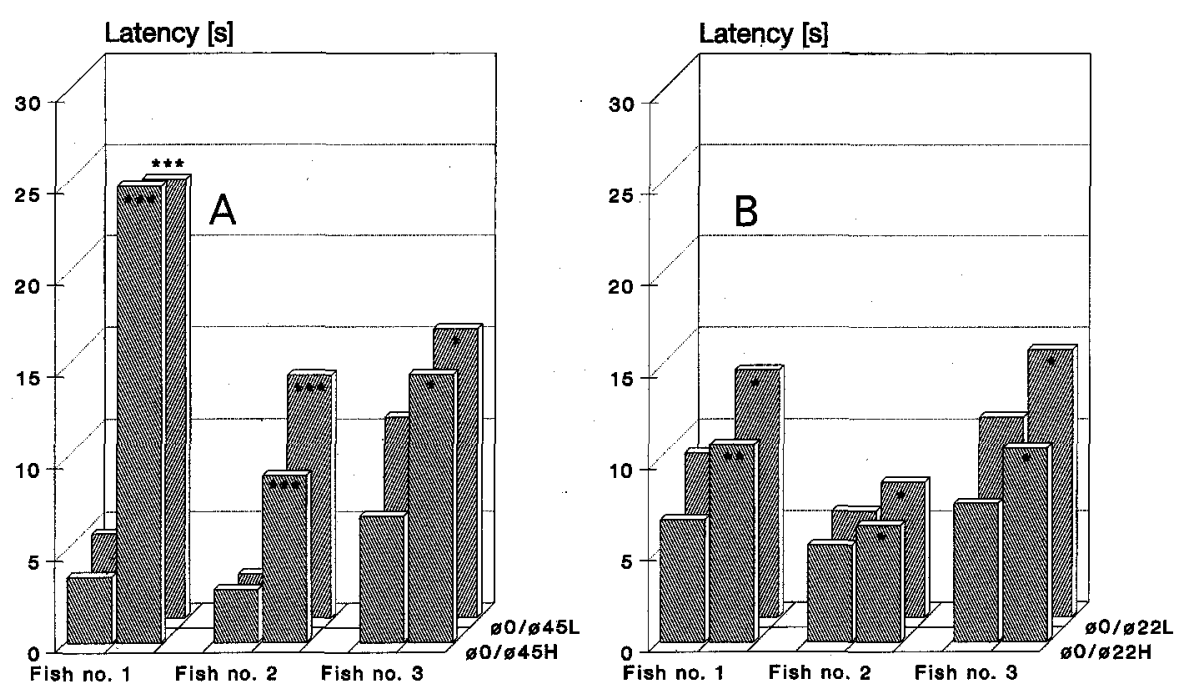

Fig. 2. Latencies for trained Eigenmannia to leave their porous pot shelter and swim to a feeding station, $35 \mathrm{~cm}$ away, in order to obtain a food reward when the rewarded stimulus, $\mathrm{S}+$, was presented. The sequence of the S+'s and S-'s were chosen randomly. Latencies were measured from stimulus onset up to the investigation of the feeding station for food by the fish. When an S- was on the electrodes (for up to $120 \mathrm{~s}$ per trial), a fish entering the feeding station received a mild punishment (a few air bubbles injected through a glass tube; for methods, see [1]). A) Fish were trained to obtain a food reward only when the signal $\phi 0$, i.e., the $S+$, was on the electrodes of a dipole next to the feeding station, not the signal $\emptyset 45$ which was the unrewarded stimulus or S- (at either high, $H$, or low, $L$, intensity; see Table 1 ). As shown in test trials which were followed by neither reward nor punishment, all fish came to the feeding station at significantly shorter latencies for $\emptyset 0$ (left columns in each pair) rather than $\emptyset 45$ (right columns). Front row of columns: the stimuli were presented at equal energy contents $(P<0.0001$ for fish nos. 1 and $2 ; P=0.04$ for fish no. 3; Mann-Withney $U$-test, one-tailed; $N=20$, i.e., $2 \times 10$ test trials for each fish). Rear row of columns: the stimuli were presented at equal peak-to-peak amplitude $(P<0.000001$ for fish nos. 1 and $2 ; P=0.025$ for fish no. $3 ; N=20$ for each fish). B) As (A), but for the signals $\phi 0$ (left column in each pair) and $\varnothing 22$ (right column in each pair). Note that also here fish showed shorter latencies when the $\mathrm{S}+$, i.e., signal $\varnothing 0$, was on the electrodes rather than the $\mathrm{S}-$. Front row of columns: differences significant at $P<0.01, P<0.05$, and $P=0.02$ for fish nos. $1-3 ; N=20$ test trials for each fish. Rear row of columns: differences significant at $P=0.04$ for the fish nos. 1 and $2, P=0.03$ for fish no. $3 ; N=20$ test trials for each fish idly decreasing intensities [8]. Because the tuberous electroreceptors have $\mathrm{V}$ shaped tuning curves with their "best" frequencies close to the fundamental frequency of the discharge $[16,17]$, higher harmonics than the second are, presumably, of little importance.)

Three naïve fish were trained to leave their porous pot shelter for a food reward, a bloodworm larva, from a feeding station $35 \mathrm{~cm}$ away when the signal designated " $\phi 0$ " (Fig. 1 A) was played back through a dipole model of an electric fish. In all experiments, the signal $\varnothing 0$ had the role of an $\mathbf{S}+$, or rewarded stimulus, the other signal waveforms (Fig. $1 \mathrm{~B}-\mathrm{E})$ the roles of an $\mathrm{S}-$, or unrewarded stimulus.

The first fish served as a control for the discrimination of the two stimuli which differed most in waveform: $\varnothing 0$ and $\varnothing 90$ (in the former signal, the second harmonic, $f_{2}$, had a phase difference of $0^{\circ}$ relative to the fundamental frequency, $f_{1}$, while this was $90^{\circ}$ in the latter). Using only test (and not training) trials, i.e., stimulus presentations followed by neither reward nor punishment, this fish clearly discriminated both signals (latencies of $3.6 \pm \mathrm{SE} 0.47 \mathrm{~s}$ for $\phi 0$ as the $\mathrm{S}+$, versus $14.0 \pm \mathrm{SE} 2.61 \mathrm{~s}$ for $\emptyset 90$ as the $\mathrm{S}-$; $P<0.0001, N=20$ test trials, one-tailed Mann-Whitney $U$-test). This result confirmed an earlier test [1] with the roles of $\mathrm{S}+$ and $\mathrm{S}-$ reversed; see the same reference for a proposed sensory mechanism. In order to find a threshold for the just noticeable shift of the $f_{2}$ phase, the S- of $\varnothing 90$ was replaced by the signal $\varnothing 45$ (Fig. $1 \mathrm{D})$. Compared to the previously used $\mathrm{S}-$, the new $\mathrm{S}-$ was more similar to the $\mathrm{S}+$ in waveform because the $f_{2}$ phase delay was halved (only $45^{\circ}$ ). In all three fish tested, the latencies for approaching the feeding station were significantly shorter when the $\mathrm{S}+$ was on the electrodes rather than the $S-$; i.e., all fish discriminated the two waveforms (Fig. $2 \mathrm{~A}$; differences individually significant for each fish).

In the above tests, the signals had been presented at equal energy contents; they differed, therefore, in peak-to-peak amplitude which is an unavoidable consequence of the different phase relationships of the signals' constituent harmonics (Table 1). Therefore, fish could have discriminated the $\mathrm{S}+$ from the $\mathrm{S}-$ by the difference in peak-to-peak amplitudes. In order to rule out this possibility, fish that discriminated the $\mathrm{S}+$ from the $\mathrm{S}-$ at 


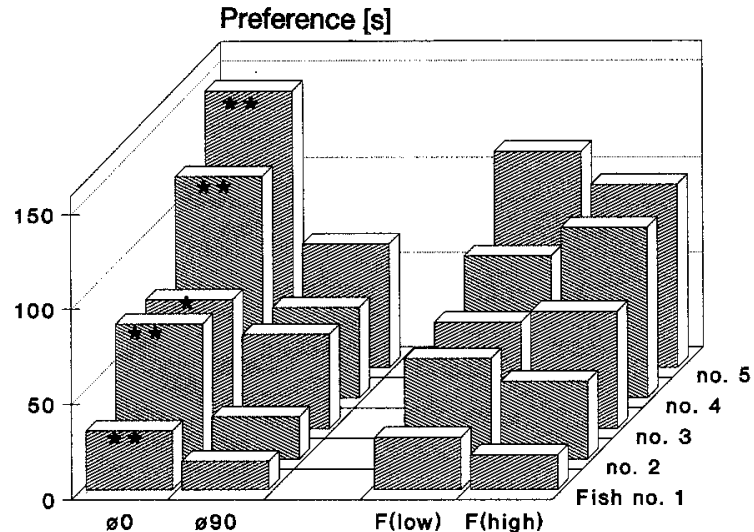

Fig. 3. Spontaneous preference for the signal $\varnothing 0$ rather than $\varnothing 90$ in a T-maze paradigm (simultaneous choice experiment) using naïve Eigenmannia, shown as mean values per trial. Two dipoles were placed next to the ends of a $250-1$ aquarium $1 \mathrm{~m}$ long (i.e., the dipoles were approximately $90 \mathrm{~cm}$ apart and $45 \mathrm{~cm}$ away from the fish's shelter). Left pair of columns: 5 fish (out of 11 tested) left their central hiding places to remain significantly longer in proximity (i.e., up to $20 \mathrm{~cm}$ ) of a dipole with the signal $\varnothing 0$ on the electrodes rather than $\varnothing 90$ (as determined by observing the fish using an overhead mirror inclined by $45^{\circ}$ and a stopwatch), although the signals had identical amplitude spectra and differed only in waveform. $P$ values were less than 0.01 for each fish except fish no. 3 (where $P=0.045$; two-tailed Wilcoxon matched-pairs signed-ranks test; $N=20$ trials for each fish, except no. 1 where $N=13$ ). Two additional fish (not shown) came so close to the same preference that they would have had $P<0.05$ in a one-tailed test. Right pair of columns: There was no systematic preference for a higher (right) or lower (left) stimulus frequency compared to a fish's own discharge frequency (two-tailed $P$-values were all greater than 0.24). However, among the six fish not shown, two showed a preference for the lower stimulus frequency $(P>0.05)$. For each stimulus presentation (of 5 -min duration per trial; at least 2 -h rest interval) the two dipoles were randomly assigned one of the two waveforms and the sign of the frequency difference from a fish's discharge frequency $( \pm 35 \mathrm{~Hz})$ such that each parameter was different for each dipole (for details, see [7])

identical energy contents were also tested at identical peak-to-peak amplitudes of the stimuli. This was done by surprise: we continued to use stimuli of identical energy contents for the training presentations, but not for the rarer test presentations (which occurred in onefifth of all trials). During test presentations, an $\mathrm{S}-$ of reduced amplitude, identical to that of the $\mathrm{S}+$, was used. Fish continued to discriminate the $\mathrm{S}+$ from the $\mathrm{S}-$ also during test presentations (Fig. 2 A, "background" columns). We conclude, therefore, that fish discriminated the $\mathrm{S}+$ from the $\mathrm{S}$ - because of their difference in waveforms rather than peak-to-peak amplitudes.

Similar tests were performed using an $\mathrm{S}$ with an only $22^{\circ}$ phase shift of its $f_{2}$, the signal $\varnothing 22$ (Fig. 1C). For both kinds of presentation, equal energy contents and also equal peak-to-peak amplitudes, the three fish discriminated the signal $\varnothing 22$ (as an S-) from the $\mathrm{S}+$ (Fig. $2 \mathrm{~B}$ ). A further halving of the remaining phase difference by using an S-with an only $11^{\circ}$ shift of the $f_{2}$ phase (Fig. $1 \mathrm{~B}$ ) was unsuccessful: two fish tested appeared unable to discriminate the signal $\varnothing 11$ as an Sfrom the $S+$ (despite a full effort as in the other signals). We therefore conclude that the just noticeable difference in $f_{2}$ phase shift, at $-3 \mathrm{~dB}$ intensity relative to the $f_{1}$, is between $22^{\circ}$ and $11^{\circ}$.

When given a simultaneous choice in a Tmaze paradigm using two dipoles, 5 out of 11 naïve Eigenmannia that received neither reward nor punishment chose to leave their central porous pot hiding place and maintain close proximity to the dipole that played back the signal $\emptyset 0$ rather than $\varnothing 90$, as measured by the time they spent within $20 \mathrm{~cm}$ of the dipoles. Two further fish came close to the same spontaneous preference of $\varnothing 0$, while the remainder did not show any statistically significant preference. The signal $\varnothing 0$ is more similar to the natural Eigenmannia discharge waveform compared to $\varnothing 90$.

We conclude that Eigenmannia is exquisitely sensitive to "pure" waveform differences, as dissociated from differences in harmonic content seen in amplitude spectra. For continuous signals this is not yet known for the mechanical senses (such as hearing, vibrational, or the sensitivity for water surface waves), although it may occur during signal onset when it seems to be useful primarily in an orientation context. For example, the goldfish detects a reversal in the polarity of sound clicks, relying on the sequence of initial compression and rarefaction during stimulus onset [18] (a similar mechanism would not have been possible in the present experimciits because of the long rise time of the stimulus signals). Sensitivity to shifting the phase of a single component in a harmonic complex tone was reported in the human; however, this was demonstrated using strongly amplitude-modulated (almost click-like) signals and was thought to depend on auditory filter response properties [19]. A true waveform sensitivity for continuous signals (as presented here) should be extremely useful in discriminating between different individuals, conspecific or not, of electric wave fish in these nocturnal creatures. The spectral phase sensitivity of these fish provides an additional parameter for the evolution of signal variety, as clearly seen in the richness of waveforms of electric organ discharges in a sympatric community of Amazonian fish [5].

We would like to thank B. Otto for assistance in many ways, and for performing some of the tests. Dr. Burkhardt kindly read an earlier version of the manuscript.

Received June 9 and July 28, 1993

1. Kramer, B., Otto B.: J. Exp. Biol. 159, 1 (1991)

2. Hopkins, C. D.: Behaviour 50, 270 (1974)

3. Hagedorn, M., in: Electroreception, p. 497 (T. H. Bullock, W. Heiligenberg, eds.). New York: Wiley 1986

4. Kramer, B., Kirschbaum, F., Markl, H., in: Sensory Physiology of Aquatic Lower Vertebrates. Adv. Physiol. Sci., Vol. 31, p. 195 (T. Szabo, G. Czék, eds). Budapest: Pergamon/Akadémiai Kiadó 1981

5. Kramer, B.: Electrocommunication in Teleost Fishes: Behavior and Experiments. Berlin: Springer 1990

6. Kramer, B., Zupanc, G. K. H.: Naturwissenschaften 73, 679 (1986)

7. Kramer, B. Otto, B.: Behav. Ecol. Sociobiol. 23, 55 (1988)

8. Kramer, B.: J. Exp. Biol. 119, 41 (1985)

9. Heiligenberg, W., Altes, R. A.: Science 199, 1001 (1978) 
10. Westby, G. W. M.: J. Comp. Physiol. 92, 327 (1974)

11. Graff, C., Kramer, B.: Ethology 90 , 279 (1992)

12. Graff, C., Kramer, B., in: Neural Mechanisms of Behavior, p. 94 (J. Erber, R. Menzel, H. J. Pflüger, D. Todt, eds.). Stuttgart: Thieme 1989
13. Hopkins, C. D., Bass, A. H.: Science 212, 85 (1981)

14. von der Emde, G., Bleckmann, H.: Naturwissenschaften 79, 131 (1992)

15. von der Emde, G.: J. Comp. Physiol. A 167, 413 (1990)

16. Scheich, H., Bullock, T. H., Hamstra Jr., R. H.: J. Neurophysiol. 36, 39 (1973)
17. Hopkins, C. D.: J. Comp. Physiol. 111 171 (1976)

18. Piddington, R. W.: J. Exp. Biol. 56, 403 (1972)

19. Moore, B. C. J., Glasberg, B. R.: J. Acoust. Soc. Am. 86, 1351 (1989)

20. Kramer, B., Weymann, D.: Behav. Brain Res. 23, 167 (1987)
Gifttiere. Von D. Mebs. Stuttgart: Wissenschaftliche Verlagsgesellschaft 1992. 280 S., 191 Abb., DM 148,-.

Mit dem Untertitel „Ein Handbuch für Biologen, Toxikologen, Ärzte und Apotheker" legt die Wissenschaftliche Verlagsgesellschaft nach den „Giftpflanzen“", den „Giftpilzen“ und den ,Teedrogen" nun einen weiteren Band dieser Reihe vor. Mit D. Mebs als Autor konnte der Verlag sicher sein, einen kompetenten Fachmann auf diesem Gebiet gefunden zu haben. Gifttiere und Vergiftungen werden umfassend und auf dem neuesten Stand dargeboten. Die einzelnen Kapitel sind übersichtlich gegliedert und umfassen nicht nur Vergiftungsumstände, Symptomatik und Therapie, sondern bringen vieles Wissenswerte über die Lebensweise der Tiere, die Anatomie des Giftapparates wie auch statistische Angaben über die Häufigkeit von Unfällen und ihren Verlauf. Wertvoll sind die Fallbeispiele, wie überhaupt der Praxisbezug in diesem Buch viel stärker zum Tragen kommt als Details aus dem theoretisch-wissenschaftlichen Bereich. Damit wird das Buch gut lesbar und informativ. Gerade hier gehen auch viele eigene Erfahrungen in den Text ein. Geradezu begeisternd sind die zahlreichen farbigen Bilder sowie die vielen gut geglückten schwarz/weißen Illustrationen. Chemische Strukturformeln finden sich nur gelegentlich und wohl mehr als Illustration, wahrscheinlich um den Abschrekkungseffekt solcher Formeln zu vermeiden. Alles in allem: Ein Buch, das seinen Anschaffungspreis wert ist. Für den im Untertitel angesprochenen Leserkreis ist es wichtig in der täglichen Praxis. Aber selbst wenn man einmal den wissenschaftlichen Informationswert außer acht läßt, so bleibt immer noch ein repräsentatives Geschenk.

G. Habermehl (Hannover)

Planet Earth. Cosmology, Geology, and the Evolution of Life and Environment. By C. Emiliani. Cambridge UK-New York-Melbourne: Cambridge University Press 1992. XI, 719 S., zahlr. Abb. u. Tab.

Cesare Emiliani ist ein 1922 geborener italo-amerikanischer Meeresgeologe. Er kommt aus der Schule des ideenreichen Chemikers Harald Urey in Chicago. Von dort angeregt, hat er die Analyse von Sauerstoff-Isotopen an Foraminiferenschalen in Tiefseesedimenten eingefuibrt und damit 1955 die zyklische Natur der Eiszeiten demonstrieren können. Er wurde so zu einem Pionier der modernen Paläozeanographie.

Sein Ideenreichtum und auch sein Temperament prägen das gewichtige Buch, obwohl das Inhaltsverzeichnis zunächst eher auf einen trockenen Lehrbuchtext hinweist: Materie und Energie / Kosmologie / Geologie / Entwicklung des Lebens und der Umwelt. Der sachliche Text wird indessen durch historische Einschübe und klar gezeichnete Abbildungen aufgelockert. Er verlockt zudem durch manche munteren Bemerkungen ständig zum Weiterlesen.

Wer etwa erfahren will, wie es zur Renaissance gekommen ist (Dante und Boccaccio sind verantwortlich!) oder zum aufrechten Gang des Menschen (damit konnten zur Weingewinnung die Trauben besser zerstampft werden!) oder warum zuweilen ganze Organismengruppen ziemlich rasch ausstarben (durch Virusinfektionen), kann das mit oder ohne Augenzwinkern des Autors nachlesen.

Die jeweils den Abschnitten angefügten Fragen ,Think“ sind besonders originell und regen zu Rückblenden an.

Dieser lockere Stil soll jedoch nicht vom eigentlichen Anliegen Emilianis ablenken. Er will dem Leser die Grundlagen moderner Naturwissenschaft nahebringen: Tatsachen, Zahlen und Theorien. Dabei weist er immer wieder auf die quantitativen Zusammenhänge hin. Fachausdrücke werden laufend erklärt, die Baupläne der wichtigsten Organismengruppen vorgestellt. Zahlreiche Tabellen bereiten ein riesiges Datenmaterial übersichtlich auf. Lücken in unseren Kenntnissen werden ehrlich dargestellt.

Bei dieser Überfülle von Fachgebieten muß natürlich manches zu kurz kommen. Die Hydrosphäre wird zum Beispiel auf rund 20, die Atmosphäre auf 30, der Vulkanismus auf 4 Seiten behandelt. Der Versuch einer historischen Perspektive zur Entwicklung der Naturwissenschaften von der minoischen bis zur Jetztzeit ist zwar verdienstvoll, aber natürlich subjektiv. Die Römer kommen dabei erstaunlich schlecht weg. Flüchtigkeits- und Druckfehler stören gelegentlich, den deutschen Leser besonders etwa das angeblich jurassische Eisenerz des Ruhrgebiets oder gar der Naturforscher Friedrich Wilhelm von Humboldt. Die Qualität der Fotowiedergaben ist leider unzureichend. Doch genug der Beckmesserei!

Emilianis sehr ehrgeiziges Ziel ist, den 